\title{
PERUSAHAAN DAN KONSERVASI KEANEKARAGAMAN HAYATI LAUT: THE RIGHT TO TOURISM vS SUSTAINABLE TOURISM
}

\author{
Ni Ketut Supasti Dharmawan Made Sarjana Putu Aras Samshitawrati \\ Dosen Fakultas Hukum, Universitas Udyana \\ Jalan Bali No. 1 Sanglah, Denpasar, Bali, 80114 \\ supasti_dharmawan@unud.ac.id
}

\begin{abstract}
Marine biodiversity developed as one of the tourism activities as well as support the right to tourism. However, the fulfillment of these rights should not making the rights of society and young generation to be reduced or neglected on sustainable tourism, particularly access to healthy environment. Therefore, it is important examining responsibility of corporation for the protection marine biodiversity. Normative legal research used to study the CBD, UNWTO, UDHR, the GPS for Business and Human Rights, Law No 5 of 1990, Law No. 10 of 2009 and Law No. 32 of 2009. As the State, corporations with other stakeholders responsible for realizing the protection and conservation for the marine diversity. Action Plans on Business and Human Rights relevan as a model to improving corporate responsibility related with protection and conservation of marine biodiversity.
\end{abstract}

Keywords : Marine Biodiversity, the Right to Tourism, Sustainable Tourism, Corporate Responsibility.

\begin{abstract}
Abstrak
Keanekaragam hayati laut dikembangkan sebagai salah satu produk dalam kegiatan kepariwisataan serta akses the right to tourism bagi wisatawan. Namun, pemenuhan hak tersebut jangan sampai mengorbankan sustainable tourism bagi generasi mendatang, khususnya akses lingkungan sehat mata rantai ekosistem keanekaragaman hayati biota laut. Oleh karenanya, penting mengkaji tanggungjawab perusahaan dalam usaha perlindungan dan konservasi. Metode penelitian hukum normatif digunakan untuk mengkaji Convention on Biological Diversity, UNWTO, UDHR, the GPs for Business and Human Rights, U.U. No. 5 Tahun 1990, U.U. No. 32 Tahun 2009, maupun U.U. No. 10 Tahun 2009. Perusahaan bersama dengan stakeholders lainnya bertanggungjawab mewujudkan perlindungan dan konservasi terhadap keanekaragaman biota laut. Model Action Plans on Business and Human Rights relevan untuk meningkatkan tanggung jawab perusahaan dalam perlindungan dan konservasi keanekaragaman hayati laut.
\end{abstract}

Kata Kunci: Keanekaragaman Hayati Laut, the Right to Tourism, Sustainable Tourism, Tanggung Jawab Perusahaan.

\section{A. Pendahuluan}

1. Latar Belakang Permasalahan

Industri kepariwisataan merupakan salah satu sektor bisnis yang mampu menyumbangkan devisa bagi negara, khususnya daerah yang memiliki pusat-pusat kepariwisataan seperti Jogja dan Bali. Perusahaan yang bergerak di bidang kepariwisataan semakin mengembangkan produk-produk jasa maupun meningkatkan standar layanan dalam rangka hospitality bagi para wisatawan. Sebagai subyek hukum yang sedang berwisata, wisatawan berhak menikmati panorama baik keindahan flora maupun fauna, suasana segar menyenangkan, nyaman dan rileks sehingga kualitas kehidupannya menjadi lebih sehat setelah berwisata maupun berlibur. Kepariwisataan merupakan bagian dari hak asasi manusia (HAM), sebagaimana diatur pada bagian Menimbang huruf $b$ Undang-Undang No. 10 Tahun 2009 Tentang Kepariwisataan yang 
secara eksplisit mengatur bahwa kebebasan melakukan perjalanan dan memanfaatkan waktu luang dalam wujud berwisata merupakan bagian dari hak asasi manusia(Undang-Undang No. 10 Tahun 2009 Tentang Kepariwisataan n.d.). Pasal 1

(1) U.U. No. 39 Tahun 1999 mengatur bahwa Hak Asasi Manusia adalah seperangkat hak yang melekat pada hakekat keberadaan manusia sebagai makhluk Tuhan Yang Maha Esa dan merupakan anugerah-Nya yang wajib dihormati, dijunjung tinggi dan dilindungi oleh negara, hukum, pemerintah, dan setiap orang demi kehormatan serta perlindungan harkat dan martabat manusia.(UndangUndang No. 39 Tahun 1999 Tentang Hak Asasi Manusia n.d.)

Berdasarkan ketentuan tersebut dapat dicermati bahwa Indonesia sebagai salah satu Negara yang ikut dalam Konvensi-Konvensi HAM telah menstransformasikan ke dalam hukum nasionalnya konsep - konsep perlindungan HAM mulai dari menghormati, menjunjung tinggi serta melindungi harkat dan martabat manusia berkaitan dengan hak asasi manusia, yaitu tidak hanya berfokus pada HAM yang sifatnya fundamental seperti the right to life namun juga HAM yang berkaitan dengan kegiatan kepariwisataan.

Perusahaan sebagai salah satu stakeholders penting dalam kegiatan kepariwisataan berinovasi secara terus menerus dalam rangka mengembangkan usaha layanan jasanya baik yang berkaitan dengan keramahtamahan (hospitality) maupun produk - produk jasa yang ditawarkannya kepada para wisatawan, termasuk di dalamnya wisata bawah laut. Wisata bahari dalam perkembangannya $m$ e $n$ $\mathrm{j}$ a d i s a la h s a t u p rod u kind u s t r i kepariwisataan yang diminati oleh para wisatawan. Melalui kegiatan wisata bahari, wisatawan dapat menikmati panorama laut dengan flora dan faunanya yang indah serta keanekaragaman hayati yang menjadi salah satu pesonanya. Perusahaan yang bergerak dalam bidang industri kepariwisataan mengembangkan produk- produk jasa industrinya agar mampu memberikan yang terbaik bagi wisatawan atau setiap orang yang sedang melaksanakan kegiatan berwisata, namun di sisi lain kegiatan industri tersebut juga membawa dampak negatif karena ekploitasi yang berlebihan terhadap keanekaragaman hayati beserta ekosistemnya yang kehidupannya saling bergantung. Bahkan mungkin berakibat kepunahan, sehingga lingkungan sehat yang berkelanjutan terkait keanekaragaman hayati laut mungkin tidak dapat dinikmati lagi oleh generasi mendatang sebagai bagian dari hak asasinya. Dengan kata lain sustainable tourism yang berhubungan dengan keanekaragaman hayati mungkin tinggal cerita indah bagi generasi mendatang, jika tidak diikuti dengan proteksi dan tanggungjawab dari para stakeholders termasuk di dalamnya perusahaan.

Berkaitan dengan latar belakang tersebut di atas, menjadi penting mengkaji tanggung jawab perusahaan berkaitan dengan perlindungan keanekaragaman hayati laut dalam pengembangan industri kepariwisataan, serta usaha-usaha yang dapat dilakukan agar para korporasi atau perusahaan mengetahui keberadaan tanggungjawabnya, sehingga dapat dicegah sedini mungkin terjadinya kehancuran dan kepunahan baik flora maupun fauna, di daerah daratan maupun perairan melalui pemenuhan tanggungjawab perusahaan.

\section{Kerangka Teori}

The Universal Declaration of Human Rights 1948 (UDHR) secara umum disepakati sebagai fondasi dari hukum internasional hak asasi manusia(The Universal Declaration of Human Rights 1948 n.d.). Dalam perkembangannya, perlindungan hak-hak asasi manusia yang diatur dalam UDHR seperti the right to life, equality before the law, the right to work, social security and education dan hak lainnya telah ditransformasikan dan dikembangkan dalam berbagai international human rights treaties, termasuk dalam the International on Civil and Political Rights (ICCPR) dan the International Covenant on Economic, Social and Cultural Rights (ICESCR). Dalam kerangka hukum internasional, telah ditetapkan kewajiban bagi setiap negara anggota dalam perjanjian internasional di bidang HAM yaitu: obligation to respect, to protect and to fulfil human rights. Obligationto protect, berarti kewajiban negara untuk menghormati bahwa negara 
harus menahan diri untuk tidak mengganggu atau membatasi kenikmatan asasi manusia. Obligation toprotect, berarti negara wajib untuk melindungi individu atau kelompok terhadap pelanggaran hak asasi manusia. Obligation to fulfil, berarti kewajiban negara untuk memenuhi yaitu kewajiban negara untuk mengambiltindakan posit ifu ntuk memfasilitasi pemenuhan hak-hak dasar manusia(Nations 2016). Christian Tomuschat mengemukakan bahwa berkaitan dengan hakhak asasi yang tercakup dalam ICESCR dijabarkan dalam tiga elemen keawajiban yaitu: an obligation to respect, an obligation to protect, and an obligation to fulfil .

Relevan dengan keberadaan hak asasi manusia baik yang pengaturannya tercantum dalam UDHR, ICCPR maupun ICESCR, secara lebih sepesifik berkaitan dengan kepariwisataan, dalam United Nation World Tourism Organization (UNWTO) Global Code of Ethics for Tourism diatur secara eksplisit hak setiap orang untuk berwisata melalui Article 7 : Right to Tourism. UNWTO tidak hanya mengatur tentang hak setiap or a n gun tukberwis a ta, na munjuga menekankan tentang kewajiban bagi seluruh stakeholders dalam rangka pengembangan kepariwisataan yang berkelnjutan sebagaimana diatur dalam Article 3:Tourism, a factor of sustainable development dan lebih lanjut dalam Article 6 diatur tentang Obligatio of stakeholders in tourism development.(The UN WTO Global Code of Ethics for Tourism n.d.)

Dalam rangka kewajiban seluruh stakeholders serta pertanggungjawabannya, tidak hanya negara, namun termasuk masyarakat, korporasi maupun perusahaan $\mathrm{s}$ e carabersa ma-sama m engus ahaka $\mathrm{n}$ terbangunnya sustainable tourism, terutama pengembangan industri kepariwisataan yang memanfaatkan lingkungan sebagai basisnya seperti keanekaragaman hayati dan biota laut, relevan digunakan landasan filosofi masyarakat Bali "Tri Hita Karana" dalam menjaga keharmonisan antara hubungan manusia dengan Tuhan, manusia dengan manusia, serta manusia dengan lingkungan serta filosofi ecosophy yang Deep Ecology dari filsuf Arne Naess dalam rangka sustainable tourism.

\section{State of the art Penelitian sebelumnya}

Daerah tujuan wisata seperti Bali pada awal perkembangannya lebih mempromosikan industri kepariwisataan yang berbasis budaya (focused on culture). Namun sejak perkembangan infrastruktur kepariwisataan pada masyarakat pantai seperti di Kuta, Sanur dan Nusa Dua, kegiatan kepariwisataan mulai dikembangkan ke arah marine environmental kepariwisataan mulai dikembangkan dari yang berbasis budaya ke wisata bahari, making it a "beach"-rather than cultural destination (Wright 2015). Wisata bahari yang berkembang seperti surfing, snorkling, diving, maupun atraksi pantai lainnya yang memikat wisatawan. Sebagai daerah tujuan wisata dunia, Bali saat ini fokus menghadapi dua persoalan besar berkaitan dengan lingkungan air khususnya pollution and freshwater scarcity terkait pengembangan wisata bahari dan terjadinya perubahan sosial (Wright 2015). Penelitian lainnya juga menunjukkan bahwa akibat keserakahan manusia, telah terjadi dampak negatif pada kondisi lingkungan hidup sumber alam hayati dan ekosistemnya, dimana puluhan juta hektar mangrove dis e panjang pantai Ind on es ia len y a p. Hilangnya mangrove juga diiringi dengan musnanhnya terumbu karang di laut yang pada akhirnya mengganggu ekosistem, juga secara ekonomi berdampak pada kalangan nelayan kecil yang kehilangan tangkapan ikannya yang biasanya hidup dan tumbuh pada trumbu karang dan mangrove (Marlang, Abdullah. \& Rina 2015).

Permasalahan penting yang dikaji dalam tulisan ini meliputi: 1. Bagaimanakah tanggungjawab perusahaan yang bergerak dalam industri kepariwisataan dalam mewujudkan perlindungan dan konservasi keanekaragaman hayati laut dalam perspektif hak asasi manusia? 2.Usaha apakah yang dilakukan dalam rangka meningkatkan pemahaman perusahaan terhadap tanggung jawab terkait konservasi keanekaragaman hayati laut dalam kegiatan kepariwisataan?

Tulisan ini bertujuan : 1. Untuk mengkaji dan menganalisis tanggungjawabperusahaan berkaitan dengan perlindungan dan konservasi keanekaragaman hayati laut dalam kegiatan kepariwisataan, khususnya dalam persepektif hak asasi manusia, dan 2 . untuk mengkaji dan menganalisis usaha yang relevan dalam rangka meningkatkan 
tanggungjawab perusahaan terkait usaha perlindungan, pelestarian dan konservasi keanekaragaman hayati laut dalam kegiatan kepariwisataan.

\section{Metode Penelitian}

Tulisan ini menggunakan jenis metode penelitian hukum(Marzuki 2005), khususnya tipe penelitian hukum doktrinal (doctrinal research). Menurut Terry Hutchinson, doctrinal research-research which provides a systematic exposition of the rules governing a particular legal category, analyss the relationship between rules, explains areas of difficulty and, perhaps, predicts future developments (Hutchinson, 2002). Sumner, et.al. menekankan pentingnya mewujudkan kualitas yang baik dalam penelitian hukum (good quality of legal research), khususnya dalam academic legal research, yaitu dengan mengidentifikasi elemen-elemen kunci, argumentasi hukum yang berbasis analisis terhadap sumber bahan hukum primer seperti: convention and treaties, statutes, and case law. Kualitas penelitian yang baik juga terwujud melalui tidak hanya meneliti bahan hukum primer, tetapi juga meneliti bahan hukum sekunder (secondary sources) seperti: proceedings, legal journal dan academic legal literature yang relevan. (Summer, Ian Curry. Kristen, Francois. Smith 2010) Dalam penulisan ini bahan hukum yang dikaji meliputi bahan hukum primer dan sekunder. Bahan hukum primer yang diteliti meliputi: The UN Convention on Biological Diversity 1992, The United Nations Convention on the Law of the Sea, The Universal Declaration of Human Rights 1948, The GATS Agreement, The UN WTO Global Code of Ethics for Tourism, Undang-Undang No. 39 Tahun 1999 Tentang Hak Asasi Manusia, UndangUndang No. 32 Tahun 2009 Tentang Perlindungan Dan Pengelolaan Lingkungan Hidup, serta Undang-Undang No. 10 Tahun 2009 Tentang Kepariwisataan. Bahan hukum sekunder teridiri dari literatur dan jurnal hukum. Pendekatan yang digunakan terdiri dari: pendekatan perundang-undangan (the Statute Approach) yang didukung oleh pendekatan konsep (Conceptual Approach) juga pendekatan perbandingan (Comparative Approach). Analisis yang digunakan adalah analisis deskriptif kualitatif.

\section{B. Hasil dan Pembahasan}

1. Tanggung Jawab Perusahan Industri Kepariwisataan dalam m e w u judkan Konservasi Keanekaragaman Hayati Laut

Secara internasional, pengakuan terhadap hak setiap orang berwisata secara eksplisit diatur dalam Article 7 Global Code of Ethics for Tourism tentang Right to Tourism (UNWTO, 2008). Pengakuan terhadap keberadaan hak setiap orang dalam berwisata sebagai bagian dari HAM fokus kajiannya menitikberatkan pada peningkatan kualitas $\mathrm{k}$ e h i d u p a m a n u s i a. ( L a h e r i 2015)Keberadaan the right to tourism dalam perspektif HAM dapat pula dicermati dari ketentuan Article 24 of the Universal Declaration of Human Rights yang mengatur bahwa Everyone has the right to rest and leisure, including reasonable limitation of working hours and periodic holidays with pay. (Dharmawan, Ni Ketut Supasti 211AD). Dalam hukum nasional Indonesia, sebagaimana telah dikemukakan sebelum nya , pengakuan tentang kepariwisataan sebagai bagian dari HAM diatur melalui Undang Undang Kepariwisataan.

Pegiat korporasi melihat peluang bisnis besar dalam kegiatan kepariwisataan, bersyukur kegiatan industrinya berkontribusi tidak hanya bagi korporasinya sendiri namun juga bagi para konsumen, wisatawan, termasuk dalam pemenuhan the right to tourism. Berbagai jenis wisata dikembangkan baik yang ada di atas permukaan tanah dengan pemandangan sungai, gunung, dan hamparan alam yang indah maupun wisata bahari dengan pesona bawah lautnya yang menakjubkan . Pengembangan kegiatan kepariwisataan sangat delematis, di satu sisi membawa peningkatan perekonomian, namun di sisi lain juga berdampak terjadinya perubahan sosialpada masyarakat di sekitarnya, seperti halnya pada daerah pariwisata di Bali. Violetta S im at u pang menge mukakan b a h w a keberadaan Pura Tirta Empul sebagai salah satuiconbuday a m s a rakat Desa Manukaya Bali telah mengalami dinamika dalam dialektika sakral dan profan. Masyarakat disatu sisi berusaha mempertahankan nilai-nilai kesakralannya, namun di sisi lain dengan berbagai faktor 
seperti faktor ekonomi untuk meningkatkan kesejahtraan menyebabkan masyarakat pengempon (pengemban) Pura dilematis

.(Simatupang 2013) Dalam konteks ini, kesadaran semua pihak baik masyarakat dan $p$ e merintahlokal, nasionalmaupun internasional secara bersama meningkatkan kepekaan terhadap pentingnya melindungi serta menghormati keanekaragaman budaya sebagai warisan budaya yang sangat bernilai sebagai salah satu penciri bangsa (Simatupang 2013).

Pengembangan aktifitas kepariwisataan sekarang ini tidak hanya berfokus pada pariwisata budaya, numun mulai banyak dikembangkan wisata bahari. Jenis wisata ini menyajikan pesona keindahan alam di dalam / dasar lautan yang luas. Dengan penyelaman misalnya, terlihat terumbu karang dengan berbagai macam jenis ikan serta biota lautnya. Perasaan takjub wisatawan muncul ketika keanekaragaman hayati terlihat di depan matanya. Berjenis-jenis spesies ikan laut, misalnya ular laut warna-warni berkelokkelok, ikan-ikan kecil beraneka warna bergerombol dan bergerak dengan lincahnya di antara terumbu karang.

Pesona flora dan fauna bawah laut, di satu sisi dapat membuat wisatawan bahagia, relax dan fresh, namun di sisi lain keindahan wisata bawah laut dan berbagai biota laut dan keragaman hayatinya sangat potensial terancam keberadaannya atau mungkin akan mengalami kepunahan yang diakibatkan oleh ekploitasi yang sangat berlebihan dan tidak bertanggung jawab dalam industri kepariwisataan. Fenomena seperti itu, tentu saja akan mengganggu keberlangsungan pariwisata, khususnya wisata bawah laut serta laut dengan keanekaragaman hayatinya kehilangan baku mutu dan fungsinya. Berbagai komponen dapat menyebabkan laut tercemar, seperti partikel kimia, limbah industri, limbah pertambangan, limbah pertanian dan perumahan, kebisingan, atau penyebaran organisme invasif (asing) di dalam laut yang berpotensi memberi efek berbahaya, termasuk komponen kegiatan kepariwisataan yang memanfaatkan lautan sebagai pesonanya menyisakan persoalan $t$ ersendiriterkaitkeberlangsungan keanekaragaman hayati lautnya. Dalam konteks ini, tanggungjawab menjadi sangat esensial untuk dikedepankan, termasuk tanggung jawab korporasi yang telah mendapatkaan manfaat finansial dari kegiatan industri bisnisnya untuk bersama-sama s t a k e holders la in ny a m ew u judkan perlindungan dan konservasi terhadap keanekaragaman hayati yang berkelanjutan..

Tanggungjawab dalam konteks tulisan ini tidak ditujukan untuk secara lebih mendalam mengkaji tanggung jawab produk yaitu tanggung jawab para produsen atas produknya yang telah dipasarkan, tanggung jawab mutlak yaitu suatu tanggung jawab yang dibebankan kepada pelaku perbuatan $\mathrm{m} \mathrm{e} l \mathrm{a} \mathrm{w}$ a $\mathrm{n} \mathrm{h} \mathrm{k} \mathrm{u} \mathrm{m}, \mathrm{m}$ a $\mathrm{pu} \mathrm{n}$ pertanggungjawaban pidana korporasi berkaitan dengan pencemaran dan kerusakan terhadap lingkungan hidup sebagaimana diatur dalam Pasal 116, namun dalam kajian ini konsep tanggung jawab korporasi lebih difokuskan pada suatu tanggung jawab perusahaan untuk bersama-sama dengan stakeholders lainnya dalam mengupayakan terwujudnya perlindungan dan konservasi bagi keanekaragaman hayati biota laut demi terwujudnya lingkungan berkelanjutan bagi generasi mendatang. Dengan kata lain, usaha tindakan nyata berbasis Good Corporate Governance dalam mewujudkan sustainable environment yang pada akhirnya juga akan mampu mewujudkan sustainable tourism berbasis eco tourism.

Dalam konteks tanggung jawab meningkatkan kegiatan kepariwisataan yang berkelanjutan, relevan dikaji sebagai landasannya Konstitusi Indonesia yaitu Pasal 5 ayat (1), Pasal 20 ayat (1), dan Pasal 33 ayat (3) Undang-Undang Dasar 1945; Bagian Menimbang point c U.U.Kepariwisataan yang menentukan bahwa kepariwisataan merupakan bagian integral dari pembangunannasional yang dilakukan secara sistematis, terencana, terpadu, berkelanjutan dan bertanggung jawab dengan tetap memberikan perlindungan terhadap nilainilai agama, budaya yang hidup dalam masyarakat, kelestarian dan mutu lingkungan hidup, juga Bagian Menimbang Undang Undang Republik Indonesia Nomor 27 Tahun 2007 Tentang Pengelolaan Wilayah Pesisir Dan Pulau-Pulau Kecil disebutkan, bahwa 
Wilayah Pesisir dan Pulau-Pulau Kecil merupakan bagian dari sumber daya alam yang dianugerahkan oleh Tuhan Yang Maha Esa dan merupakan kekayaan yang dikuasai oleh negara, yang perlu dijaga kelestariannya dan dimanfaatkan untuk sebesar-besar kemakmuran rakyat, baik bagi generasi sekarang maupun bagi generasi yang akan datang;

Pemanfaatan pulau-pulau Kecil dan Perairan di sekitarnya juga termasuk ekosistem yang ada di dalam bawah laut diprioritaskan untuk kegiatan : pendidikan dan pelatihan, penelitian dan pengembangan, budidaya laut serta pariwisata dan sebagainya. Jadi guna kepentingan pariwisata dalam hal ini wisata bawah laut yang menonjolkan keindahan biodat bawah laut serta keanekaragaman hayati yang ada, undang-undang inimemprioritaskandi s e l e $\mathrm{ng}$ g a r a k a n kegiatan-kegiatan terkait pariwisata bawah laut tersebut. Tentu saja hal ini sesuai dengan aturan yang ada harus memperhatikan : memenuhi persyaratan pengelolaan lingkungan, memperhatikan kemampuan sistem tata air setempat serta menggunakan teknologi yang ramah lingkungan. Penting untuk memahami dan mengimplementasikan ketentuan yang mengatur pelindungan dan konservasi keanekaragaman hayati termasuk biota laut.

Keanekaragaman Hayati, yang juga dikenal dengan istilah " $B$ i o l o g i c c a l diversity"dituangkan pengaturannya dalam Article 2 of the UN Convention on Biological Diversity 1992 (CBD): "Biological diversity" means the variability among living organism from all sources including, inter alia, terrestrial, marine and other aquatic ecosystems and the ecological complexes of which they are part: this includes diversity within species, between species and of ecosystems. Berdasarkan difinisi yang diatur dalam Pasal 2 CBD, Robin Kundis Craig (2005) mengidentifikasi ada tiga (3) unsur penting dalam pengaturan definisi biodiversity yaitu: genetic diversity, species diversity, dan ecosystem diversity.(Craig 2005) Berdasarkan definisi Pasal 2 CBD tersebut selain diketahui unsur-unsur pentingnya terdiri dari 3 unsur, juga menekankan bahwa keanekaragaman hayati mencakup kajian tentang keanekaragaman hayati di lingkungan terristtrial (daratan), marine (lautan) serta other equitic ecosystems and the ecological complexes which they are part (ekosistem air lainnya).

Indonesia adalah salah satu negara anggota dari CBD, yang telah meratifikasi berdasarkan Undang-Undang No. 5 Tahun 1994 Tentang Pengesahan United Nations Convention on Biological Diversity. Berdasarkan terjemahan resmi dari Pasal 2 Konvensi Perserikatan Bangsa-Bangsa Keanekaragaman Hayati, secara lebih rinci dapat diketahui bahwa "keanekaragaman hayati" ialah keanekaragaman di antara makhluk hidup dari semua sumber, termasuk diantaranya, daratan, lautan dan ekosistem akuatik lain serta kompleks-kompleks ekologi yang merupakan bagian dari keanekaragamannya, mencakup keanekaragaman di dalam spesies, antara spesies dan ekosistem.

Keberadaan keanekaragaman hayati baik yang berada di lautan, daratan maupun ekosistem air lainnya sangat penting untuk dilindungi dan dilestarikan karena keberadaannya memiliki konstribusi yang sangat besar bagi kualitas kehidupan manusia. The United Nations Environmental Programme (UNEP), menekankan bahwa punahnya keanekaragaman hayati akan mengancam suplay makanan, panorama yang indah untuk mendukung kesempatan berwisata, serta ketersediaan sumber bahan kayu, obat-obatan dan juga energi (the loss of biodiversity threatens our food supplier, opportunities for recreation and tourism, and sources of wood, medicins and energy) (UNEP - Secretariat of the Convention on Biological Diversity 2000).Article 2 CBD mengatur bahwa keragaman hayati meliputi: genetic diversity, species diversity, dan ecosystem diversity baik yang bersumber, tumbuh maupun berkembang di darat, di laut, maupun ekosistem air lainnya. Dengan demikian, dibutuhkan suatu kesadaran dalam rangka melindungi beranekaragaman hayati tidak hanya yang bertumbuh dan berkembang di darat, akan tetapi juga yang bertumbuh di perairan termasuk didalamnya keanekaragaman hayati biota laut. Untuk menekankan betapa pentingnya melindungi keberadaan dari biodiversity, Indonesia sebagai negara anggota, pada Bagian Menimbang huruf. b. mengatur bahwa keanekaragaman hayati yang meliputi ekosistem, jenis dan genetik yang mencakup 
hewan, tumbuhan dan jasad renik (microorganism), perlu dijamin keberadaan dan keberlanjutannya bagi kehidupan.

Keberadaan keanekaragaman hayati biota laut telah banyak dikritisi oleh para peneliti, ahli, maupun pemerhati lingkungan dengan mengemukakan bahwa keberadaannya terancam oleh berbagai ekploitasi maupun aktivitas manusia yang tidak bertanggung jawab . Craig mengemukakan karena pertumbuhan populasi manusia yang demikian pesat dengan prilakunya membawa pengaruh terhadap kehidupan biota laut, serta mengancam keberadan keragaman biota laut yang sesungguhnya merupakan bagian penting dari mata rantai keberlangsungan kehidupan bumi dan ekosistemnya. Sebagai contoh, hasil setudinya menunjukkan di tahun 1995 sebanyak $22 \%$ perikanan laut telah dieksploitasi secara berlebihan, bahkan mungkin sampai habis (Craig, 2005). Sejumlah aktivitas manusia yang dikategorikan sebagai pencemaran laut (marine pollution) telah mengancam keanekaragaman biota bawah laut (marine biodiversity), termasuk pembangunan daerah wilayah pesisir pantai, perusakan habitat laut, dan penangkapan ikan yang berlebihan (over fishing).

Keperihatinan terhadap ekosistem biota laut yang semakin terancam juga secara eksplisit dikemukakan dalam Bagian Menimbang huruf. c. U.U. No. 5 Tahun 1994 tentang Pengesahan CBD yang menentukan bahwa keanekaragaman hayati sedang mengalami pengurangan dan kehilangan yang nyata karena kegiatan tertentu manusia yang menimbulkan terganggunya keseimbangan sistem kehidupan di bumi, yang pada gilirannya akan mengganggu berlangsungnya kehidupan manusia. Selain dalam berbagai konvensi termasuk CBD, dalam konteks lingkungan hidup secara lebih general, sesungguhnya telah mulai dibahas dalam Konferensi Internasional di Stockholm yang kemudian dikenal dengan sebutan Deklarasi Stockholm 1972, dan dipandang sebagai Deklarasi yang melahirkan konsep hukum lingkungan hidup yang berorientasi pada keseimbangan antara pengelolaan, pemanfaatan dengan upaya pelestarian sumber daya alam dan lingkungan hidup (Marlang \& Maryana, 2015).

Pengaturan tentang perlindungan dan konservasi keanekaragaman hayati termasuk di dalamnya biota laut sangat penting untuk senantiasa ditegakkan, terutama dalam rangka ekosistem yang berkelanjutan, yang senantiasa menempatkan hubungan seimbang dan harmoni, saling ketergantungan antara manusia dengan alam sekitarnya yang berbasis deep ecology dengan pendekatan ecosophy serta relevansinya dengan hak asasi manusia. Pemanfaatan sumber-sumber daya keanekaragaman hayati pada saat sekarang ini memiliki relevansi terhadap terjaminnya sustainable environment (lingkungan berkelanjutan) termasuk didalamnya dalam rangka mendukung sustainable tourism. Berkaitan dengan kegiatan usaha, Indonesia juga telah mengatur dalam tataran produk yang mewajibkan para korporasi atau masyarakat yang ingin memasarkan suatu produk yang bersentuhan dengan sumber daya hayati dalam kegiatan usaha wajib mencantumkan Logo Ecolabel sebagaimana diatur melalui Peraturan Menteri Lingkungan Hidup Republik Indonesia No. 2 Tahun 2014 Tentang Pencantuman Logo Ecolabel.

Dalam rangka memahami Konservasi Sumber Daya Alam Hayati, penting komponen-komponen yang tergolong sebagai sumber daya hayati yaitu tumbuhan, satwa, maupun unsur non-hayati disekitarnya sebagaimana diatur dalam Pasal 1 Ayat (1)U.U. No. 5 Tahun 1990. Dalam rangka usaha perlindungan dan konservasi penting untuk memahami komponen sumber daya alam hayati sebagaimana diatur dalam Pasal 1 Ayat (2) U.U. No. 5 Tahun 1990 ditujukan pada pengelolaan dan pemanfaatannya berorientasi pada peningkatan kualitas dan nilai keanekaragaman hayati yang berkelanjutan. Semua pihak yang peduli terhadap usaha-usaha konservasi, termasuk korporasi penting mengetahui karakteristik keanekaragaman sumber daya hayati dan ekosistemnya yang ternyata keberlangsungan kehidupannya sangat tergantung satu dengan yang lainnya dan saling mempengaruhi. Tugas kita adalah untuk memastikan dan menjamin agar mata rantai kehidupan tersebut tidak terputus, karena jika terputus 
akan mengganggu ekosistemnya, dan pada akhirnya kemanfaatan untu pemenuhan hak asasi manusia generasi mendatang tentang sumber daya hayati yang baik dan sehat juga akan terganggu. Sesungguhnya UndangUndang juga sudah mengatur perihal karakteristik dari kenakeragaman hayati dan ekosistemnya.

Undang-Undang No. 5 Tahun 1990 tampak secara tegas mewujudkan pendekatan ecosophy, yaitu mengatur bahwa sesungguhnya ekosistem sumber daya alam hayati saling tergantung dan mempengaruhi, serta menekankan kepada seluruh umat manusia dalam rangka memanfaatkan keberadaan ekosistem tersebut wajib menjamin keseimbangannya, karena mereka adalah suatu kesatuan mata rantai yang saling berhubungan, serta meningkatkan kualitas keragamannya. Pada bagian pertimbangan umum huruf c. dari U.U. No. 5 Tahun 1990 diatur bahwa unsur-unsur sumber daya alam hayati dan ekosistemnya pada dasarnya saling tergantung antara satu dengan yang lainnya dan saling mempengaruhi sehingga kerusakan dan kepunahan oleh salah satu unsur akan berakibat terganggungnya ekosistem.

Perlindungan dan konservasi biota bawah laut merupakan bagian yang tidak terpisahkan dari perlindungan tentang kelautan dalam konteks yang lebih luas sebagaimana dapat dicermati dari UU No. 32 Tahun 2014 Tentang Kelautan. P a s a 1 langka 1 UU No. 32 Tahun 2014 mengatur definisi laut adalah adalah ruang perairan di muka bumi yang menghubungkan daratan dengan daratan dan bentuk alamiah lainnya, yang merupakan kesatuan geografis dan ekologis beserta segenap unsur terkait, dan yang batas dan sistemnya ditentukan oleh peraturan perundang-undangan dan hukum internasional. Ditambahkan dalam Pasal 1 angka 2. bahwa kelautan adalah hal yang berhubungan dengan Laut dan/atau kegiatan di wilayah Laut yang meliputi dasar Laut dan tanah di bawahnya, kolom air dan tanah di bawahnya, kolom air dan permukaan Laut, termasuk wilayah pesisir dan pulau pulau kecil.

Berdasarkan ketentuan Pasal 1 tersebut di atas dapat dicermati bahwa perlindungan tentang biota bawah laut terakomodir oleh ketentuan U.U. Tentang Kelautan, karena sebagaimana ditentukan dalam Pasal 1 angka 2 , kelautan juga mencakup "dasar laut dan tanah di bawahnya". Dalam rangka pengelolaan kelautan yang memiliki keunggulan komparatif dan kompetitif serta berorientasi pada ketersediaan sumber daya kelautan dalam jangka waktu panjang (sustainable), Undang-Undang Kelautan mengaturnya melalui ketentuan Pasal 1 angka

7. Lebih jauh diatur tentang pengelolaan kelautan berbasis pada kegiatan konservasi laut sebagaimana diatur berdasarkan Pasal 1 angka 8 U.U. Kelautan. Prinsip ekonomi biru juga dianut dalam U.U. Kelautan tercantum melalui Penjelasan Pasal 14 Ayat 1 U.U. Kelautan. Gunter Paulli, pionir dari konsep ekonomi biru, yang sekaligus menunjukkan kelemahan dari konsep ekonomi hijau, melalui konsepnya dikemukakan bahwa ekonomi biru adalah pengembangan ekonomi yang berwawasan kelautan, bukan melakukan eksploitasi terhadap sumber daya laut, namun berorientasi pada pemeliharaan dan perlindungan ekosistem kelautan. Konsep ini merupakan bentuk kebijakan industrialisasi kelautan dan perikanan yang berlandaskan modernisasi. Ekonomi biru ini adalah percepatan untuk pertumbuhan ekonomi dengan memanfaatkan potensi kelautan dan perikanan.

Senada dengan konsep ekonomi biru,dalam U.U. Kepariwisataan juga mengatur prinsip kepariwisataan yang mengedepankan hubungan manusia dengan Tuhan, hubungan manusia dengan manusia serta hubungan anusia dengan lingkungan sebagimana yang juga merupakan nilai-nilai dari filosofi Tri Hita Karana di Bali, tampaknya nilai-nilai tersebut berkesesuaian atau harmoni dengan filosofi ecosophy yang Deep Ecology dari filsuf Arne Naess. Pendekatan Deep Ecology yang juga dikenal sebagai filsafat ecosophy dikemukakan oleh Arne Naess pada era tahun 1972-an. Naess mengemukakan bahwa teori- teori ilmu modern terlalu abstrak, tidak $m$ a $m p u m e n$ jelaskanrealitas yangsesungguhn $\mathrm{y}$ a, i a m e $\mathrm{g}$ e $\mathrm{m}$ u k a k a n pendekatan deep ecology, yang pada intinya memperlihatkan tentang kesadaran akan keterkaitan internal 
ekosistem ; egalitarianisme ekologi (semua spesies memiliki hak yang sama untuk hidup dan berkembang); prinsip keberagaman dan simbiosis; posisi anti kelas sosial; apresiasi kompleksitas ekologi membuka keasadaran manusia bahwa sekalipun seorang pekerja lapangan ekologis "memperoleh rasa hormat yang mendalam, diterapkannya "prinsipprinsip otonomi daerah dan desentralisasi. Bahkan Naess, menambahkan insofar as ecology movements deserve attention they are ecophilosophical rather than ecologic (Sessions, 1987). Dalam konteks pendekatan Deep Ecology, Fritjop Capra menunjukkan bagaimana pandangan mechanical atomistik pada abad ke 17 telah digantikan dengan energy metaphysic yang ditransformasikan dari timur yaitu dari Taoisme, Hinduism, dan Buddhism(Sessions, 1987).

Lingkungan yang berkelanjutan dalam kegiatan kepariwisataan menjadi tanggungjawab seluruh stakeholders, demikian diatur dalam the UN WTO, Global Code of Ethics berdasarkan Article 3: Tourism, a factor of sustainable development. Dalam ketentuan Pasal 3 ini, secara tegas diatur bahwa seluruh stakeholders dalam rangka pengembangan kegiatan kepariwisataan harus menjaga lingkungan yang natural dalam rangka lingkungan berkelanjutan, pertumbuhan ekonomi yang berkelanjutan dan kesejahtraan bagi generasi yang akan datang. Dengan demikian, seluruh stakeholders bertanggungjawab, itu berarti juga menjadi tanggung jawab korporasi atau perusahaan.

Tanggung jawab untuk mewujudkan tersedianya keanekaragaman hayati yang berkelanjutan juga diatur dalam Bagian Umum Penjelasan U.U. No. 32 Tahun 2009 Tentang Perlindungan Dan Pengelolaan Lingkungan Hidup mengatur bahwa lingkungan hidup yang baik dan sehat merupakan hak asasi manusia dan hak konstitusional bagi setiap warga negara Indonesia . Negara, pemerintah dan seluruh pemangku kepentingan berkewajiban untuk melakukan perlindungan dan pengelolaan lingkungan hidup yang berkelanjutan agar lingkungan hidup tetap menjadi sumber dan penunjang hidup bagi rakyat Indonesia serta mahluk hidup lainnya. Kembali disini, selain negara memiliki tanggung jawab, demikian pula korporasi sebagai salah satu unsur dari pemangku kepentingan memiliki tanggung jawab.

\section{Kegiatan Desiminasi Untuk Peningkatan Perlindungan Dan Konservasi Keanekaragaman Hayati Laut Dalam Kegiatan Kepariwisataan Bahari}

Dalam dunia hukum terkenal adanya adagium yang menyebutkan "Setiap orang dianggap tahu akan hukum". Dengan kata lain, berbagai ketentuan hukum yang telah diundangkan dan telah berlaku sebagai hukum positif bagi masyarakatnya, dengan sendirinya masyarakat dianggap telah mengetahuinya, meskipun dalam kenyataannya tidaklah demikian adanya. Sehubungan dengan hal tersebut, sangatlah penting dilakukan usaha-usaha desiminasi maupun sosialisasi kepada masyarakat termasuk masyarakat pengusaha tentang keberadaan suatu ketentuan perundangundangan agar mereka lebih memahami dan turut serta melaksanakan kewajiban maupun tanggungjawabnya. Seperti misalnya, penting secara berkelanjutan dilakukan desiminasi perundang-undang yang berkaitan dengan lingkungan hidup dan konservasi keanekaragaman hayati kepada perusahaan kepariwisataan yang memanfaatkan keanekaragaman hayati laut dalam pengembangan bisnisnya. Model pendekatan yang umumnya diterapkan dalam regulasi berkaitan dengan hak asasi manusia, seperti misalnya keberadaan Action Plan dan kewajiban melaksanakan Action Plan bagi stakeholders terkait relevan untuk diaplikasikan.

Dalam persepektif HAM, berkaitan dengan tanggung jawab perusahaan, secara internasional rekomendasi dari John Ruggie, yang dikenal sebagai the Special Representative of Secretary General (SRSG) on Business and Human Rights, pada tahun 2008 dengan rekomendasinya Three Pillars yaitu: the "Protect, Respect and Remedy" telah didukung (endorsed) pada tanggal 16 Juni 2011 oleh the UN Human Rights Council (Ruggie 2014). Sekarang rekomendasi John Ruggie telah dielaborasi dalam The UN Guiding Principles on Business and Human Rights (GPs). Tiga pilar 
utama dalam GPS terdiri dari pilar pertama tentang the State duty to protect human rights, pilar kedua dari GPs tentang the corporate responsibility to respect human rights. Dalam konteks ini, tanggung jawabnya bukan suatu kewajiban semata-mata bagi perusahaan to respect human rights, namun lebih dari itu, yaitu: all business enterprises worldwide this is formed as global standard of expected conduct.

Tanggung jawab dalam konteks ini meskipun tertuang dalam global standard, namun dikaitkan sekali lagi dengan Good Corporate Governance (GCG), sudah sepantasnya the responsibility to respect human rights diimplementasikan oleh para korporasi. Pilar yang terakhir dalam GPs adalah access to remedy. Untuk mengimplementasikan GPs dituangkan dalam Action Plan of GPs secara lebih kongkrit yang juga mengelaborasi usahausaha perlindungan dan konservasi terhadap lingkungan dalam rangka sustainable environment, maupun ketentuan-ketentuan lainnya yang berkaitan dengan usaha proteksi dan konservasi terhadap lingkungan penting untuk secara berkesinambungan didesiminasikan kepada korporasi baik oleh pemerintah, akademisi ( universitas), maupun stakeholders lainnya, agar tujuan pengaturan tersebut terwujud. Ketentuan hukum maupun model-model guiding principles baik yang ranahnya nasional maupun internasional dilaksanakan oleh perusahaan sebagai bagian dari pelaksanaan GCG.

\section{Simpulan}

1. Berdasarkan ketentuan internasional seperti UDHR 1948, CBD 1992, the UNWTO Global Code and Ethics 2011, the UN GPs 2011 dan berbagai perundang-undangan nasional seperti

U.U. No. 5 tahun 1990, U.U. No. 32 Tahun 2009, dan U.U. No. 10 Tahun 2009, perusahaan termasuk perusahaan yang bergerak dalam bidang industri kepariwisataan bahari memiliki tanggungjawab bersama-sama dengan stakeholders lainnya dalam mewujudkan perlindungan dan kegiatan konservasi keanekaragaman hayati laut dalam rangka lingkungan hidup berkelanjutan, pemenuhan the right to tourism bagi generasi sekarang juga bagi generasi masa datang.

2. Usaha dalam meningkatkan partisipasi korporasi maupun perusahaan dalam mewujudkan perlindungan dan konservasi terhadap keanekaragaman hayati laut relevan menggunakan model desiminasi Action Plan for Activities on Business and Human Rights y a $\mathrm{g}$ didesiminasikan secara berkelanjutan baik oleh pemerintah, universitas dan stakeholders lainnya kepada para penggiat korporasi maupun perusahaan.

\section{Saran}

Diharapkan pemerintah bersama lembaga terkait agar mensosialisasikan ketentuan-ketentuan hukum yang berkaitan dengan perlindungan dan konservasi lingkungan beserta Action Plan-nya secara berkelanjutan terutama kepada para stakeholders yang berkitan dengan kegiatan kepariwisataan bahari, agar keberadaan keanekaragaman hayati biota laut tidak punah dan terus bermanfaat dalam rangka pemenuhan hak asasi manusia akan sumber ekosistem yang memberikan kemenfaatan baik bagi generasi bagi generasi sekarang maupun yang akan datang.

\section{DAFTAR PUSTAKA}

Craig, Robin Kundis. 2005. "Protecting International Marine Biodiversity: International Treaties and National Systems of Marine Protected Areas." Journal of Land Use 20(2): 340341,347.

Dharmawan, Ni Ketut Supasti, et.al. 211AD. "The Right to Tourism Dalam Perspektif Hak Asasi Manusia Di Indonesia." Jurnal Kertha Patrika, 36(2): 35.

Laheri, Putu Eva. 2015. "Tanggung Jawab Negara Terhadap Kerugian Wisatawan Berkaitan Dengan Pelanggaran Hak 
Berwisata Sebagai Bagian Dari Hak Asasi Manusia." Jurnal Magister Hukum Udayana 4(1): 130.

Marlang, Abdullah. \& Rina, Maryana. 2015. Hukum Konservasi Sumber Daya Alam Hayati Dan Ekosistemnya. Jakarta: Mitra Wacana Media.

Marzuki, Peter Mahmud. 2005. Penelitian Hukum. Jakarta: Prenada Media.

Nations, United. 2016. "Human Rights L a w." ht t p : / / w w w . u n . org/en/s e ctions/universaldeclaration/human-rights-law (March 31,2017).

Ruggie, John Gerard. 2014. Global Governance and "New Governance Theory": Lessons from Business and Human Rights.

Simatupang, Violetta. 2013. Hukum Kepariwisataan Berbasis Ekspresi Budaya Tradisional. Bandung: Alumni.

Summer, Ian Curry. Kristen, Francois. Smith, Tina van der Linden. \& Jet Tigchelaar. 2010. Research Skill Instruction for Lawyers. Netherlands: Nijmegen School of Law.

"The UN WTO Global Code of Ethics for Tourism."

"The Universal Declaration of Human Rights 1948.

"Undang-Undang No. 10 Tahun 2009 Tentang Kepariwisataan.

"Undang-Undang No. 39 Tahun 1999 Tentang Hak Asasi Manusia.'UNEP Secretariat of the Convention on Biological Diversity. 2000. "Sustaining Life on Earth How the Convention on Biological Diversity Promotes Nature and Human Well-Being." : 5. https://www.cbd.int/iyb/doc/prints/cbdsustain-en.pdf(October 28, 2016).

Wright, Thomas. 2015. Water, Tourism, And Social Change: A Discussion of Environmental Perceptions In Bali. Den Pasar: Program Studi Magister Kajian Pariwisata Universitas Udayana in cooperation with Buku Arti. 